\title{
The Shape of Things To COME? On The Dynamics of SuICIDE ATtaCKS ANd TaRgeted Killings
}

\author{
David A. Jaeger* \\ College of William and Mary, University of Bonn, and IZA
}

Temporary Address:

Visiting Research Fellow

IZA

Scaumburg-Lippe Str. 7/9

D-53113 Bonn

Germany

Tel.: +492283894511
Permanent Address:

Associate Professor

Department of Economics

College of William and Mary

Williamsburg, VA 23187-8795

USA

Tel.: +1 7572212375

Email: djaeger@wm.edu

and

M. Daniele Paserman

Boston University, Hebrew University, NBER, CEPR, and IZA

\author{
Associate Professor \\ Department of Economics \\ Boston University \\ 270 Bay State Road \\ Boston, MA 02215 \\ USA \\ Tel.: +1 6173534389
}

Email: paserman@bu.edu

February 2008

*Corresponding Author.

We thank Tatiana Slobodnitsky, Tamar Roth, Yaron Aronshtam, and Eran Ben-Ari for outstanding research assistance, Suhair Abdi and Yael Handelsman of B'Tselem for discussions about data as well as providing data on suicide bombings, Maj. Gen. (ret.) Netzach Mashiach for providing us the data on the separation barrier, and Noam Zussman for providing us the data on assassination attempts. We also thank Paul Manna and seminar participants at the University of Aarhus for useful comments. David Jaeger acknowledges financial support from the IZA and the Samuel Neaman Institute. Daniele Paserman acknowledges financial support from the Samuel Neaman Institute. 


\title{
The Shape of Things to Come? On the Dynamics of Suicide Attacks and Targeted Killings
}

\begin{abstract}
In this paper we examine the dynamics of suicide attacks and targeted killings in the Second Intifada. We find evidence that the targeted killings of Palestinian leaders by Israel reduce realized Palestinian violence. We find, however, that intended Palestinian violence is increasing at low levels of targeted killings, but decreasing at higher levels. We find that suicide bombings that kill at least one Israeli lead to a subsequent increase in the incidence and levels of Palestinian fatalities. Our results do not support the notion that suicide attacks and targeted killings follow the "tit-for-tat" pattern that is commonly postulated in the literature.
\end{abstract}

Keywords: suicide terrorism, targeted killings, assassinations, Second Intifada, Palestinians, Israel 
Unlike a conventional war involving ground or air combat on a battlefield between nation-states with armies of (roughly) equal capacity fighting to claim territory, several recent conflicts have taken place in populated civilian areas between groups with substantial differences in military capacity. These conflicts may include targeted killings (assassinations) of specific leaders on one side and suicide attacks on other - policies primarily designed to incapacitate or demoralize the opponent rather than to directly claim territory. In both cases, civilians are either deliberately targeted (as with suicide attacks) or are likely to be killed in the process (as with targeted killings). This kind of decentralized, somewhat sporadic, and clearly psychologically oriented warfare may be one of the defining characteristics of many of the conflicts of the 21st century.

In the long-standing conflict between the Palestinians and Israel, the Second Intifada has been characterized by the increased use of suicide attacks by the Palestinians and an increased number of Israeli targeted killings of Palestinian militants of all ranks. Nearly half of the over 1,000 Israeli fatalities in the Second Intifada have been caused by suicide attacks, while about 8 percent of more than 4,100 Palestinian fatalities have occurred during targeted killings. Of these, nearly 40 percent were not the targeted individual(s). ${ }^{1}$ While neither of these tactics was introduced during the Second Intifada, ${ }^{2}$ their heightened prevalence has resulted in their being perceived as the defining characteristics of the conflict.

The Palestinian-Israeli conflict, while perhaps the best known, is not the only one in which suicide attacks and targeted killings have been used. Hezbollah engaged in suicide attacks against Israeli, French, and U.S. targets in Lebanon between 1982 and 1985, while Israel also

\footnotetext{
${ }^{1}$ These statistics are taken from http:/www.btselem.org (last seen 12 June 2007) and are current through 31 May 2007.

${ }^{2}$ Israel has engaged in assassinations of Palestinians since the 1970s (Byman 2006). There were more than 10 suicide attacks by Hamas and Islamic Jihad during the First Intifada (Pape 2006).
} 
engaged in targeted killings of Hezbollah leaders. More recently, both before and after the suicide attacks of 11 September 2001, the U.S. has attempted targeted killings of al-Qaeda leaders in Afghanistan, Pakistan, Sudan, and Yemen, as well as Uday and Qusai Hussein in Iraq, ${ }^{3}$ despite laws prohibiting assassinations. ${ }^{4,5}$ Russia has also been accused of assassinating several Chechen nationalist leaders, ${ }^{6}$ while the Chechen separatists have engaged in numerous suicide attacks against Russian targets, and these stand out for the high proportion of women amongst the attackers. While the frequency of targeted killings and suicide attacks in the PalestinianIsraeli conflict is much higher, it shares certain similarities with these other conflicts. In particular, they all involve an occupying army and a militant opposition that wants the occupiers to leave (Pape 2006). Understanding the relationship between these two forms of violence in the Palestinian-Israeli conflict may shed light on how effective they are in other conflicts as well.

In this paper we use data on violence and attempted violence in Israel and the Occupied Territories to examine the short-term dynamics of the two "signature" policies of the Second Intifada. Our primary interest is to estimate empirically whether suicide attacks generate a violent Israeli response and whether targeted killings lead to changes in Palestinian violent behavior. Our results suggest that Israel reacts to suicide attacks in the short run, with the number and incidence of Palestinian fatalities rising after a fatal suicide attack. This is true both for the overall number of Palestinian fatalities, and for the number of Palestinian fatalities in

\footnotetext{
${ }^{3}$ See Kaplan (2006) for a discussion of U.S. targeted killings policy.

${ }^{4}$ Section 5(g) of Executive Order 11905 provided that "No employee of the United States Government shall engage in, or conspire to engage in political assassination," and was signed by President Gerald Ford on 19 February 1976. It was superseded by Executive Order 12036, Sections 2-305 and 2-309 which prohibited direct and indirect participation in assassinations, respectively, signed by President Jimmy Carter on 26 January 1976. Executive Order 12333, Sections 2.1 and 2.2, signed by President Ronald Reagan on 4 December 1981 is still in effect and also prohibits direct and indirect participation in assassination (removing the word "political" from the 1976 Executive Order). In none of the orders, however, is "assassination" defined.

${ }^{5}$ Yael Stein (2003) has argued that Israeli assignations are immoral and similarly illegal according to international law. Our goal in this paper is not to address the legality or morality of Israeli targeted killings, but to evaluate their effectiveness with regard to preventing future Israeli fatalities.

${ }^{6}$ Specifically, Dzhokhar Dudayev, on 21 April 1996; Zelimkhan Yanderbiyev, on 13 February 2004 in Qatar; Aslan Maskhadov, on 8 March 2005; and Shamil Basayev, on 10 July 2006.
} 
targeted killings. On the other hand, targeted killings of Palestinian leaders have a short-term deterrent or incapacitation effect: the overall number of Israeli fatalities, and the number of Israelis killed in suicide attacks fall in the first week after a targeted killing We also find some evidence that intended Palestinian suicide attacks increase following successful targeted killings (i.e. those in which the target was killed), although this response is non-linear: intended Palestinian violence increases when one moves from zero to one or two targeted killings per month, but then decreases at higher levels.

In the next section we discuss the previous literature on suicide terrorism and targeted killings. We then briefly discuss our empirical approach. In Section III we describe our data on violence and intended violence. In Section IV we discuss the prevalence of suicide attacks among overall Israeli fatalities and the prevalence of targeted killings among all Palestinian fatalities. In Section V, we estimate the Israeli reaction to realized and intended suicide attacks by the Palestinians. We examine realized Palestinian reactions to targeted killings in Section VI and discuss intended Palestinian actions in Section VII. In Section VIII we discuss the implications of our results and offer some conclusions.

\section{Previous Literature}

There is a growing literature on the motivations and causes driving suicide terrorism. Pape $(2003,2006)$ asserts that suicide terrorism has a strategic value vis-à-vis the terrorists' opponent. After documenting the global pattern of suicide terrorism beginning in the 1980 s, he concludes that it is used primarily to coerce democracies (like Israel) to relinquish occupied territory. He uses descriptive evidence to conclude that neither military offensives like targeted 
killings nor bargaining concessions are likely to quell suicide terror and that the best strategy for doing so is preventive measures like barriers.

In contrast, Bloom (2004) asserts that Palestinian suicide terrorism is driven primarily by a desire by the competing factions to win the support of the Palestinian public by responding to Israeli attacks. She asserts that Israeli targeted killings are "seemingly irrational... only generat[ing] more victims," and concludes that "the Israelis and Palestinians appear to be in a deadlocked battle of assassinations-suicide bombing-assassination-suicide bombing in an unending causal loop" (p. 83-84). This is, of course, an empirical question, which we will directly test below.

Like Bloom, Kydd and Walter (2002) suggest that suicide bombings serve another "internal" purpose, namely to derail peace processes near their potential conclusions, denying the desires of more moderate groups. They examine the pattern of Hamas attacks in Israel between 1993 and 2001 and conclude that their timing influenced the Israeli election of 1996, which led to the Likud Party and Benjamin Netanyahu coming to power; similarly, shortly after the outbreak of the Second Intifada, Likud Party leader Ariel Sharon defeated the more moderate Ehud Barak (head of the Labor Party) in the February 2001 direct elections for Israeli Prime Minister. In both cases, peace negotiations broke down after Likud took power. Bueno de Mesquita and Dickson (2007) make a somewhat similar argument, hypothesizing that extremist groups may attack the central government in the attempt to provoke a counterterrorism response that will radicalize the population, at the expense of support for a more moderate faction. Gupta and Mundra (2005) attempt to test some of these hypotheses by examining low-frequency (biyearly) data on suicide attacks carried out by Hamas and Islamic Jihad between 1991 and 2003. 
They find that there is a degree of political strategic interplay between the two factions, and that acts of political provocation by Israel are important determinants of suicide attacks.

The literature on anti-terror measures, and targeted killings in particular, has also grown in recent years. Enders and Sandler (1993) examine the effectiveness of antiterrorism policies in the context of transnational terrorism while examining whether different modalities of terrorist activity are substitutes or complements for one another. They find that most interventions have little effect on the overall level of terrorist activities.

Brophy-Baermann and Conybeare (1994) build a theoretical rational expectations model, which suggests that the optimal rate of retaliation to terror is one that is rule-based rather than discretionary. They test this theory on data on terrorist attacks and retaliation in Israel between 1968 and 1989 and find that, in general, Israel's retaliations had little effect on the steady-state level of terrorist attacks.

More specific to the Second Intifada, Jacobson and Kaplan (2008) develop a sequential game-theoretic model of suicide bombings and targeted killings. They use numerical methods to simulate the equilibrium level of violence under various assumptions on the patience (or, alternatively, discount rates) of the two sides. David (2003) discusses Israel's policy of targeted killings and asserts, although he does not show empirically, that the net effect of targeted killings is the likely increase in Palestinian violence against Israelis. He nevertheless claims that targeted killings can be morally justified on deterrence, revenge, and retribution grounds.

Frisch (2006) presents descriptive evidence that Israel's counter-terror policies have reduced suicide bombings and other forms of violence. A more rigorous statistical approach is used by Kaplan et al. (2005), who proposed a "terror stock" model and examine how targeted killings and pre-emptive arrests influence the subsequent recruitment of terror operatives. They 
find that targeted killings of Palestinians serve to increase, while pre-emptive arrests reduce the stock of potential terrorists. Kaplan, Mintz, and Mishal (2006) allow for a more flexible functional form, but find largely similar results.

Zussman and Zussman (2006) empirically estimate the effect of targeted killings on investors' sentiments about the Israeli economy. They find that the killing of senior Palestinian military leaders leads to an increase in Israeli stock prices while the killing of a senior Palestinian political leader has an opposite (and larger) effect.

Unlike other studies that examine either Israeli or Palestinian actions, Jaeger and Paserman (2008) examine the dynamics of the overall level of violence between them and found that Israel reacts in a systematic way towards realized Palestinian violence, with little evidence of a systematic reaction by the Palestinians towards Israeli violence. This approach is unique in the literature on the Palestinian-Israeli conflict because it treats both sides symmetrically rather than focusing only on the reaction of one side or the other.

Like Jaeger and Paserman (2008) we examine both sides of the conflict, but our focus here is on suicide attacks and targeted killings. Symmetric treatment of both suicide attacks and targeted killings allows us to examine the full dynamics of the relationship between them and to asses their effectiveness. Unlike Zussman and Zussman (2006), we examine directly how targeted killings and suicide attacks affect the violent responses of Israel and the Palestinians, respectively. In particular, we test Bloom's (2004) assertion that the Palestinians and Israeli's are engaged in a perpetual causal tit-for-tat cycle of suicide attacks and targeted killing reprisals. 


\section{Motivation}

Both suicide attacks and targeted killings are designed to induce fear in the opposite side and to provoke them to take a future course of action that is more desirable for the offensive side. Both actions also carry the objective of delivering retribution for past violence. Suicide attacks by Palestinians may serve a number of strategic goals (inducing Israel to make territorial concessions, derailing the peace process, improving the popularity of the faction responsible in the eyes of the Palestinian public, etc.), but they are also likely to prompt an Israeli response. Targeted killings of Palestinian militants have the objective of incapacitation by the deliberate destruction of human capital; however, they may also boost the desire for vengeance among the Palestinians, facilitating the recruitment of potential suicide bombers, and therefore increase the level of violence against Israeli targets. All of these factors suggest that whether targeted killings and suicide attacks raise or lower the level of violence is ultimately an empirical question.

Our empirical strategy assumes the existence of reaction functions for both sides of the form, without loss of generality,

$$
R_{t}=f\left(I_{t-1}, P_{t-1}, \mathbf{X}_{t}\right)
$$

where $R_{t}$ is the realized or intended reaction, (e.g., for the Israeli reaction, $R_{t}$ indicates Palestinian fatalities or targeted killings; for the Palestinian reaction, $R_{t}$ indicates Israeli fatalities or suicide attacks), $I_{t-1}$ is Israeli fatalities (either overall or caused by suicide attacks), $P_{t-1}$ is Palestinian fatalities (either overall or targeted killings), and $\mathbf{X}_{t}$ is a vector of other covariates (e.g. different periods in the conflict). We present results below that include more than one lag, and our estimates give us the net effect of the different motives discussed above.

Relative to the literature, our approach in this paper has a number of distinct advantages. First, we limit our focus to suicide attacks and targeted killings, two actions that are designed 
specifically to inflict fatalities on the other side. This improves upon previous research by abstracting from more conventional "combat" fatalities, which are possibly incurred in defensive actions. Second, for both types of events we can identify in the data both successful and unsuccessful attempts. This allows us to glean some information on how the two sides react not only to realized levels of violence, but also to intended violence. Third, both the timing and the success of a suicide attack or an assassination attempt depend to a large extent on random factors: Will the target be killed? How many collateral fatalities will there be? Will the explosive belt detonate? How many individuals happen to be in the café when the bomb goes off? This randomness strengthens the causal interpretation of our results.

We should sound here two words of warning. First, our analysis by necessity examines the short-term dynamics of suicide bombings and targeted killings. Despite the length of the Second Intifada, when using weekly data we still have a limited number of observations on which to base our estimation. While we can of course speculate on the effects of targeted killings and suicide bombings on Palestinian and Israeli behavior, respectively, over the entire length of the conflict (and beyond), such "longer-term" effects cannot be estimated econometrically. Secondly, the goal of our analysis is to provide a systematic account of the dynamic link between Israeli and Palestinian violence. As such, it necessarily must refrain from investigating the effects of single episodes of violence. While analysis based on case studies or anecdotes can be useful for understanding the causes and effects of specific incidents, our approach allows us to estimate the average effect of targeted killings and suicide bombings on the dynamic of violence over the whole course of the Second Intifada. As such, our results are useful for understanding the overall dynamics of the conflict. 


\section{Data}

\section{Overall Fatalities}

Our data on fatalities on both the Palestinian and Israeli sides is taken from the web site of B'Tselem, an Israeli human rights organization. ${ }^{7}$ In its statistics section, the site records in detail every fatality (excluding suicide bombers) during the second Intifada. The data includes information on the date and circumstances (including suicide attacks and targeted killings) of the fatal wounding, the date of death (most often the day of the fatal wounding), the age, gender and locality of residence of the victim. Among the advantages of this data set are its comprehensiveness and the symmetrical treatment of fatalities on both sides, something that is unavailable in neither the official statistics compiled by the Israeli Ministry of Foreign Affairs or the Palestinian National Information Centre, nor in the unofficial statistics compiled by the Palestinian Red Crescent Society. The information published by B'Tselem is widely thought to be accurate and reliable. We use data from 20 September 2000 to 15 January 2005, the day on which Mahmoud Abbas assumed the presidency of the Palestinian Authority following the death of Yasser Arafat.

\section{Targeted Killings}

In addition to the information on targeted killings resulting in a fatality (although not necessarily that of the target) available in the B'Tselem data, we also employ the data compiled by Zussman and Zussman (2006) on targeted killings, which they generously shared with us. Contrary to the B'tselem data, the Zussman and Zussman data set also includes information on targeted killing attempts that did not result in any fatalities. Using data from four different sources (both Israeli and Palestinian), these authors compiled a list of all targeted killings carried

\footnotetext{
${ }^{7} \mathrm{http}: / / \mathrm{www}$. btselem.org
} 
out by Israel from September 2000 to 30 April 2004, a shorter time period than the one available from B'Tselem. The data record the date and circumstances of each assassination attempt, the identity and the organizational affiliation of the target, whether the target was killed, and the total number of fatalities caused by the assassination attempt. We define an attempt as successful if the target is killed.

Zussman and Zussman's definition of a targeted killing is somewhat broader than that employed by B'Tselem, although the targeted killings identified by B'Tselem are not a strict subset of those identified by Zussman and Zussman. In our primary analysis we use all of the (fatal) targeted killings identified in the B'Tselem data and supplement those with the additional non-fatal targeted killings identified by Zussman and Zussman. ${ }^{8}$ We also perform sensitivity analysis in which we use only the targeted killings identified by Zussman and Zussman and get qualitatively very similar results.

\section{Suicide Bombings and Intended Palestinian Violence}

One concern in our analysis is that realized Palestinian violence (i.e., violence that results in an Israeli fatality) may not fully capture Palestinian actions, particularly if Israel endogenously adjusts its preventive measures in response or anticipation of Israeli targeted killings. We therefore employ two measures of intended Palestinian violence. We use the data on fatalities from B'Tselem to identify individuals who were killed via a suicide attack. We supplement these data with information on unsuccessful (i.e. non-fatal) suicide attacks from an unpublished list of 114 fatal and non-fatal suicide attacks compiled by B'Tselem and graciously provided to us. We measure intended violence as the sum of fatal and non-fatal suicide attacks. The second measure of intended violence comes from data collected by the Israeli Defense Force (IDF). The IDF has

\footnotetext{
${ }^{8}$ Our analyses using targeted killings therefore cover the period 29 September 2000 to 30 April 2004.
} 
collected data on the total number of successful and of prevented suicide attacks from the beginning of the Intifada until the end of 2004. Prevented attacks include those that were either thwarted by a preventive action by the IDF or the General Security Service, or were not carried out because of "work accidents" or other failures in the execution of the attack. These data are publicly available on a monthly frequency from the IDF web site. Unfortunately, higher frequency data on successful and unsuccessful attacks is not made available to the public for security reasons.

\section{Other Measures}

We include indicators for seven distinct phases in the conflict, from its inception in September 2000 until 15 January 2005, when Mahmoud Abbas assumed the Presidency of the Palestinian Authority two months after the death of Yasser Arafat. These phases are characterized by differences in the intensity and the character of the overall level of violence between the Palestinians and Israel.

The first phase of the conflict (29 September 2000 to 6 February 2001) ran from the outbreak of violence in until the February 2001 Israeli elections, which saw the fall of the Laborled coalition government headed by Ehud Barak and the installment of a national unity government led by Likud leader Ariel Sharon. The second phase (7 February 2001 to 11 September 2001) coincided with the first several months of the Sharon government until the September 11, 2001 attacks on New York City and Washington, DC. According to several observers, these attacks gave the Israeli government a "green light" to pursue more proactive measures against militant and terrorist groups, including incursions into the Palestinianadministered Territories. The third phase (12 September 2001 to 28 March 2002) marks the 
period after the September 11 attacks until the beginning of "Operation Defensive Shield" (ODS), a large-scale military offensive against Palestinian militant and terrorist infrastructure in the West Bank. ODS and its aftermath mark the fourth phase of the conflict (29 March 2002 to 24 June 2002). Two other important events occurred around this time: a) the beginning of construction of Israel's separation barrier in the north of Israel and around Jerusalem on 15 June 2002 and b) U.S. President George W. Bush's Middle East speech on 24 June 2002, which called for a new Palestinian leadership and laid out the "road map," Bush's vision for the long-term solution of the conflict. We take Bush's speech as the beginning of the fifth phase of the conflict (25 June 2002 to 28 June 2003). The sixth phase (29 June 2003 to 19 August 2003) is marked by a Palestinian-declared ceasefire, which ended when Hamas took responsibility for a large suicide bombing on a Jerusalem bus. The seventh, final, and longest phase of the conflict (22 August 2003 to 15 January 2005) is the period after the ceasefire until Mahmoud Abbas assumed the presidency of the Palestinian Authority.

We also include a measure of the length of the separation barrier between Israel and the West Bank Territories in our analysis. This measure is constructed from information on the length, location, and beginning and ending dates for construction of different sections of separation barrier, generously provided to us by Maj. Gen. (ret.) Netzach Mashiach of the IDF. On the basis of these dates and locations, we linearly interpolated the daily growth in length of the barrier. A similar barrier surrounding Gaza was completed in 1994, prior to the beginning of the Second Intifada. 


\section{Prevalence of Suicide Attacks and Targeted Killings}

During the Second Intifada, suicide attacks became the primary method used by the violent Palestinian factions. In Table 1 we present tabulations of the number of Israeli fatalities during each year of the conflict (until 15 January 2005) as well as the share of those fatalities that occurred as a result of a suicide attack. This share shows a clear increase from 0 to 0.688 between 2000 and 2003. In 2004, both the number of overall Israeli deaths declined, as well as the share due to suicide attacks. Nevertheless, it is clear that suicide bombings have become the prevalent means by which the Palestinians attack Israelis.

The fourth and fifth rows show the number successful and unsuccessful suicide attacks. The rise and then decline in the share of Israeli deaths due to suicide attacks is due both to the number and the "efficiency" of those attacks. The last three rows of Table 1 show the average share of suicide attacks resulting in Israeli fatalities, and the number of Israeli deaths per successful and total attacks, measures of the "efficiency" of suicide attacks. The number of overall Israeli fatalities and the share due to suicide attacks declined after 2003. This may indicate a shift in Palestinian methods or (more likely) an increase in Israel's ability to detect and deter Palestinian attacks.

The time-series pattern of targeted killings shows similar, although not identical trends.

In Table 2 we present tabulations of the prevalence of targeted killings among Palestinian fatalities using both B'Tselem data on targeted killings that resulted in at least one fatality, as well as data from Zussman and Zussman (2006), which also include targeted killings that may not have resulted in any fatalities. The results from the two datasets are generally consistent, showing a substantial increase in the share of targeted killings in Palestinian fatalities: this share rises from about 5 percent in 2001 to about 15 percent in 2004. The two datasets differ, 
however, in the share of collateral fatalities in targeted killings, with the B'Tselem data showing that about $38 \%$ of the fatalities in targeted killings were not the targets themselves while the Zussman and Zussman show 59\% of the fatalities in targeted killings were not the intended target. The two datasets also differ in the number of targeted killings, with Zussman and Zussman showing substantially more, particularly in 2002 and 2003.

The last two rows of each panel in Table 2 show measures of Israeli efficiency in targeted killings. On average during the conflict, by both measures, Israel was successful more than 80 percent of the time in killing the targeted individual. The average number of individuals reported killed in a targeted killing attempt increased from about 1.5 in $2000-2001$ to about 3.5 to 4.0 in 2004, depending on the data source.

\section{Israeli Reaction to Suicide Attacks and Other Palestinian Violence}

We turn now to estimating Israel's the response to suicide attacks. We estimate the model

$$
\begin{gathered}
P_{t}^{\text {all }}=\alpha+\beta_{1} I_{t-1}^{s}+\beta_{2} I_{t-2}^{s}+\gamma_{1} I_{t-1}^{u}+\gamma_{2} I_{t-2}^{u}+ \\
\delta_{1} I_{t-1}^{\text {oth }}+\delta_{2} I_{t-2}^{\text {oth }}+\mathbf{X}_{t}^{\prime} \Theta+\varepsilon_{t}
\end{gathered},
$$

where $P_{t}^{\text {all }}$ is a measure of total Palestinian fatalities in period $t ; I_{t}^{s}$ is the number of successful (i.e. causing Israeli fatalities) suicide attacks in period $t$; $I_{t}^{u}$ is the number of unsuccessful (i.e. not causing Israeli fatalities) suicide attacks in period $t ; I_{t}^{\text {oth }}$ is the number Israeli fatalities not due to suicide attacks suicide attacks in period $t ; \mathbf{X}_{t}$ is a vector of variables controlling for the different periods in the conflict as well as the length of the West Bank separation barrier, and $\varepsilon_{t}$ is a random error term capturing non-systematic determinants of the number of Palestinian fatalities in period $t$. We define the variables $I_{t}^{s}$ and $I_{t}^{u}$ so that they are in the same metric (number of 
attacks) to facilitate comparison of the magnitude of the estimated coefficients. The $\beta$ and $\gamma$ coefficients measure Israel's response to the occurrence of successful and unsuccessful suicide attacks, respectively, in terms of the subsequent changes in Palestinian fatalities. ${ }^{9}$

We estimate equation (1) via ordinary least squares (OLS) and use the number of total Palestinian fatalities in week $t$ as our primary measure of $P_{t}^{\text {all }}$. OLS will estimate the causal effect of the independent variables on $P_{t}^{\text {all }}$ if they are orthogonal to $\varepsilon_{t}$. The inherent randomness in the execution of suicide attacks suggests that this condition is likely to be met. Whether an attack is successful or not (in terms of Israeli fatalities) is at least partially a function of chance as shown in Table 1, just over half of suicide attacks were successful. It $i$ s possible that Israel increases its level of vigilance in anticipation of its attacking the Palestinians. If this were the case, then the OLS estimates of $\beta$ and $\gamma$ would be downward biased and even potentially negative. Our estimated coefficients should therefore be taken as lower bounds of the true effects. $^{10}$

In Table 3 we present results from estimating equation (1) using data from B'Tselem for the period 29 September 2000 to 15 January 2005. The first two columns present the coefficients and standard errors of our basic specification, where the dependent variable is the total number of Palestinian fatalities. We find that a successful suicide attack in week $t-1$ on average leads to approximately 6 more Palestinian fatalities in week $t$; we can reject the null hypothesis that this coefficient is equal to zero at the 5 percent level. ${ }^{11}$ Consistent with the results in Jaeger and Paserman (2006), we find that Israel reacts in a significant and positive way to

\footnotetext{
${ }^{9}$ In our results we include two weekly lags. Jaeger and Paserman (2008) examine the lag structure of the dynamic of overall fatalities in detail and conclude that it is only the first two weeks after an Israeli or Palestinian fatality that are relevant to subsequent violence. We adopt their lag structure here.

${ }^{10}$ Alternatively, the estimated coefficients could be biased towards zero if the Palestinians could successfully implement preventive measures after a fatal suicide attack. Given the technology available to the two sides, we view this scenario as fairly implausible.

${ }^{11}$ All standard errors in the paper at heteroskedasticity-consistent and estimated using White's (1980) method.
} 
fatalities in period $t-1$ that are not caused by a suicide attack, and we can reject the null hypothesis that both coefficients on other Israeli fatalities are jointly equal to zero. ${ }^{12}$ Neither of the coefficients on failed suicide attacks are statistically significantly different from zero at conventional levels. They are also not jointly different from zero.

We also analyze the effect of suicide attacks on Palestinian fatalities in targeted killings, rather than on the total number of Palestinian fatalities. This allows us to shed light on the hypothesis that suicide attacks and targeted killings are linked to each other in an unending causal loop (Bloom, 2004). Moreover, fatalities in targeted killings are the outcome of a deliberate action initiated by Israel (as opposed to other Palestinian fatalities, that may occur as a result of violence initiated by the Palestinians themselves), and therefore are more directly informative about Israel's strategic reaction to Palestinian violence. In the second two columns of Table 3 we present the estimated coefficients and standard errors of equation (1), where the dependent variable is the number of Palestinians killed in targeted killings (both targets and bystanders). The results are very similar to those obtained with total Palestinian fatalities on the left hand side: Israel reacts systematically to suicide attacks by intensifying its use of targeted killings in the first week after a successful Palestinian attack; on the other hand, there is no reaction to failed suicide attacks, and contrary to the previous specification, there is no evidence that Israel carries out more targeted killings in response to other Israeli fatalities.

The results in Table 3 provide strong evidence that Israel reacts to realized violence but not to intended violence that does not lead to a fatality. If intended but unrealized suicide attacks revealed some information about future Palestinian terrorist activities, we would have expected to see a reaction to this type of violence as well. Since this is not the case, we are led to believe

\footnotetext{
${ }^{12}$ This test is similar to that proposed by Granger (1969) and can be interpreted as a test of causality as long as the orthogonality assumption between the error term and the regressors is met.
} 
that perhaps the primary motivation for the Israeli reaction is to satisfy the public's desire to dispense retribution to the Palestinians, as David (2003) asserts. ${ }^{13}$

To explore this issue further and to check the robustness of the results in Table 3, we estimated the model in equation (1) with a variety of different specifications for $P_{t}^{\text {all }}$. These results are summarized in Table 4 . The first column simply reproduces the sign and significance level of the primary coefficients of interest from the first two columns of Table $3 .{ }^{14}$ In the next two columns, we modify the dependent variable, while still using data at the weekly frequency: in the second column the dependent variable is the the natural logarithm of $(1+$ the number of fatalities in week $t),{ }^{15}$ while in the third column the dependent variable is an indicator for whether there were any Palestinian fatalities in week $t$ (we call this the incidence specification). In the two rightmost columns, we use data at a daily frequency and use either the number of Palestinian fatalities on day $t$ as the dependent variable or an indicator for any Palestinian fatalities on day $t$; in this specification, the right hand side variables are defined as sums of the relevant measures over the periods 1 to 7 and 8 to 14 days prior to day $t .^{16}$

We find consistent evidence that Israel responds in a positive and statistically significant way to successful suicide attacks. At both daily and weekly frequencies, we find that the first week's lag has a significant effect on Palestinian fatalities in the levels or log-levels regressions. In the incidence regressions we find that it is the second lag on days with successful suicide

\footnotetext{
${ }^{13}$ Some recent studies provide empirical support to the notion that violence radicalizes the victimized population: Berrebi and Klor (2007) document that Israeli voters are more likely to vote for right-wing parties in response to Palestinian terrorist attacks; Jaeger et al. (2008) find that violence against Palestinians leads to a decrease in support for the moderate Fatah faction.

${ }^{14}$ In these robustness tests we experiment with a number of different transformations of the dependent variable "total Palestinian fatalities." The results are essentially identical when the dependent variable is the number of Palestinian fatalities in targeted killings. Results available from the authors upon request.

${ }^{15}$ We add 1 because there are three weeks in which there are no Palestinian fatalities and $\log (0)$ is undefined. This is a standard transformation when the number of " 0 " observations is small relative to the total number of observations.

${ }^{16}$ We do not estimate the log specification at the daily frequency because of the large number of days with zero Palestinian fatalities.
} 
attacks that has a statistically significant effect on subsequent Palestinian fatalities. We find a virtually identical pattern for days with other Israeli fatalities. There is no evidence, however, that failed suicide attacks induce Israel into subsequent action. Overall, the results are not sensitive to the frequency at which we measure the outcomes nor to functional form. They strongly indicate that fatal suicide attacks lead to subsequent escalations in Israeli violence against Palestinians.

\section{Palestinian Reaction to Targeted Killings}

We define the Palestinian reaction function in a way similar to that for the Israelis. We estimate the model

$$
\begin{gathered}
I_{t}^{\text {all }}=a+b_{1} P_{t-1}^{s}+b_{2} P_{t-2}^{s}+c_{1} P_{t-1}^{u}+c_{2} P_{t-2}^{u}+ \\
d_{1} P_{t-1}^{o t h}+d_{2} P_{t-2}^{o t h}+\mathbf{X}_{t}^{\prime} \Phi+\xi_{t}
\end{gathered},
$$

where $I_{t}^{\text {all }}$ is a measure of total Israeli fatalities in period $t ; P_{t}^{s}$ is the number of successful targeted killings in period $t$ (i.e. those where the target was killed); $P_{t}^{u}$ is the number of unsuccessful targeted killings in period $t$ (i.e. where the target was not killed, although there could have been other individuals killed during the action); $P_{t}^{\text {oth }}$ is the number of Palestinian fatalities not due to targeted killings in period $t ; \mathbf{X}_{t}$ is defined as above, and $\xi_{t}$ is a random error term capturing non-systematic determinants of the number of Israeli fatalities in period $t$.

As with the Israeli reaction function, we first estimate equation (2) using OLS with data measured on a weekly basis. OLS will give a consistent estimate of the parameters if the variables in the model are uncorrelated with $\xi$. Here we are somewhat more concerned that $\xi$ contains effects such as Israeli preventive measures that might be correlated with $P^{s}, P^{u}$, and $P^{\text {oth }}$. This would happen, for example, if Israel were more likely to close its borders or increase its 
level of alertness when it is taking aggressive actions in the West Bank and Gaza. Jaeger and Paserman (2008) present evidence from daily frequency regressions, however, indicating that even though border closings (a proxy measure for Israeli vigilance) at time $t$ are related to both Israeli and Palestinian fatalities in the two weeks prior to $t$, inclusion of border closings in the Palestinian reaction function to all Palestinian fatalities has little effect on the estimated coefficients. We are therefore reasonably confident that omitted variable bias is not a major issue in our regressions. Nevertheless, we explore the issue of intended Palestinian suicide attacks in the next section, which should be relatively less affected by Israeli vigilance.

In Table 5 we present our baseline estimates of the Palestinian reaction function. The key explanatory variables are constructed from the B'Tselem data on targeted killings that resulted in a fatality, augmented with information from Zussman and Zussman (2006) on non-fatal targeted killings. The data cover the period from 29 September 2000 to 30 April 2004, when Zussman and Zussman's data end. The first two columns report the coefficients and standard errors with the total number of Israeli fatalities as the dependent variable. We find that that there is a statistically significant negative effect of successful targeted killings on Israeli fatalities in the first week's lag, indicating that killing militants in one of the violent Palestinian factions has an incapacitation or deterrent effect. As for the effect of failed targeted killings on subsequent Israeli fatalities, we find that the coefficients on both lags are negative, but not statistically significant, either individually or jointly. In contrast to Jaeger and Paserman (2008), we find that the first lag of the number of other Palestinian fatalities raises the number of subsequent Israeli fatalities. ${ }^{17}$ The next two columns in the table present the coefficients and standard errors for the model with the number of Israeli fatalities in suicide attacks as the dependent variable. The

\footnotetext{
${ }^{17}$ This discrepancy may be due to the slightly different time period under examination, and in fact is not very robust to different specifications of the Palestinian reaction function, as seen below.
} 
results are again very similar: the number of Israeli fatalities in suicide attacks falls in the first week after a successful targeted killing, and it appears to rise in the second week, but the coefficient is not statistically different from zero. Failed targeted killings and other Palestinian fatalities, on the other hand, have no effect on the number of Israeli fatalities in subsequent weeks.

We test the robustness of these results by using alternative definitions of targeted killings (the augmented B'Tselem data as well as all of the Zussman and Zussman data), different frequencies (weekly and daily), and different definitions of $I_{t}^{\text {all }}$. We present these results in Table 6. The first column reproduces the results from the first two columns of Table 5 using the augmented B'Tselem data while the second column presents results using the same levels model estimated with the Zussman and Zussman data. The third and fourth columns estimate these same two regressions using the incidence specification for the dependent variable. The fifth through eighth columns repeat this exercise using daily rather than weekly data. In general, we find some evidence that successful targeted killings have a negative effect on the level of subsequent Israeli fatalities, at least in the short term. In the incidence specification at the weekly frequency, we find with both sources of data that successful targeted killings increase the probability of an Israeli fatality two weeks later. We find no effect of successful targeted killings in the daily frequency incidence regressions, although we find that unsuccessful targeted killings increase the probability of an Israeli fatality in the subsequent week, using both definitions of targeted killings. We find evidence in the levels regressions at a weekly frequency and the incidence regressions at a daily frequency that other Palestinian fatalities lead to subsequent Palestinian violence. While the overall pattern of estimates of the Palestinian reaction function 
in Table 6 is somewhat nuanced, the most consistent result is that successful targeted killings reduce the subsequent number of Israeli fatalities in the first week after the event. ${ }^{18}$

\section{Intended Palestinian Violence}

The results of the last section suggest that successful targeted killings diminish subsequent Israeli fatalities. It is possible, however, that Israel increases its preventive measures in the wake of a targeted killing, and that realized violence understates the degree of Palestinian actions. To address this issue, we now consider intended Palestinian suicide attacks. We measure intended suicide attacks in two ways. First, we combine the B'Tselem measures used in Tables 3 and 4 on successful and unsuccessful suicide attacks into one measure of intended suicide attacks. This is a rather narrow definition in the sense that it only measures suicide attacks in which suicide bombers themselves were killed. It does not measure attacks in which the explosive device did not detonate or in which the attacker was apprehended before exploding his or her device. We therefore use a second, broader, but somewhat unclearly defined, measure from the IDF on "suicide bombings." This measure, according to the IDF, includes information on realized and prevented suicide attacks. ${ }^{19}$ Unfortunately, these data are publicly available only at a monthly frequency.

\footnotetext{
${ }^{18}$ If we restrict attention only to Israelis killed in suicide attacks, we still find that the coefficient on the first lag of successful targeted killings is almost always negative and significant, while some of the other puzzling estimates from Table 6 go away. Results available upon request.

${ }^{19}$ It appears that the IDF sometimes uses the terms "suicide attacks" and "terrorist attacks" interchangeably: see for example http://www1.idf.il/dover/site/mainpage.asp?sl=EN\&id=22\&docid=16703 and http://www1.idf.il/SIP_STORAGE/DOVER/files/6/31646.doc. In an unusually detailed announcement released on December 252003 (http://www1.idf.il/dover/site/mainpage.asp?clr=1\&sl=HE\&id=7\&docid=26412, in Hebrew), the IDF describes in detail 10 prominent "prevented attacks". These include the arrests of five suspected suicide bombers, four suspected drivers, four suspected planners of attacks against Israelis, and one militant suspected of acting as a liaison between the central command of the terrorist cell and the suspected suicide bomber. In at least one case, it is quite clear that the planned attack was not a suicide attack.
} 
In Table 7 we present regression results that mirror those in Table 5, except that the dependent variable is now the number of intended (total successful and unsuccessful) suicide attacks from the B'Tselem data, rather than all Israeli fatalities. We find little evidence that successful or unsuccessful targeted killings affect intended Palestinian suicide attacks. This suggests that the deterrence/incapacitation effect we found of targeted killings on the level of realized Israeli fatalities does not hold with respect to intended suicide attacks. We have also estimated a similar model using an indicator variable for any intended suicide attacks as the dependent variable, with similar results.

The B'Tselem data on intended suicide attacks is, as noted above, somewhat limited in scope and likely miss some Palestinian actions. It is possible that with a broader measure of Palestinian intentions we would find different results. To explore this issue, we turn now to monthly frequency regressions and the IDF measure of intended suicide attacks. To this point in the analysis we have relied on a linear specification in the independent variables with two weeks of lags. There is evidence, however, that the relationship between targeted killings and intended violence is not linear at a monthly frequency. In Figure 1 we graph our two measures of intended suicide attacks (from B'Tselem and the IDF) against the number of successful targeted killings in the previous month. Figure 1 makes clear that one targeted killing increases the number suicide attack attempts in the subsequent month, but that additional successful targeted killings reduce the number of suicide attack attempts, particularly with regard to the IDF data. On average, however, the months following those with targeted killings have more suicide attack attempts than those with no targeted killings. Regardless, Figure 1 suggests that a quadratic in targeted killings is likely to be the correct specification. Given the monthly frequency of the data 
and the limited number of observations at our disposal (42 months), we include only one lag of the targeted killing and other Palestinian fatality variables, but with a quadratic functional form.

In Table 8 we present results from regressions at a monthly frequency on realized and intended violence. In the first column the dependent variable is the B'Tselem measure of intended suicide attacks. We find that successful targeted killings have a statistically significant relationship with intended suicide attacks. The results imply that intended suicide attacks rise up to 2.9 targeted killings in the previous month, and then decline. ${ }^{20}$ We find no statistically significant relationship between the other measures of Israeli violence (unsuccessful targeted killings and other Palestinian fatalities) and intended Palestinian attacks. In the second column of Table 8, we present results using the IDF measure of intended Palestinian attacks. This yields results that are qualitatively very similar to those using the B'Tselem measure. We again find a statistically significant relationship between successful targeted killings and intended Palestinian violence. The results imply that intended Palestinian attacks peak when there are 3.3 successful targeted killings in the previous month

One substantial difference between the two regressions is the pattern of coefficients on the period variables. Most notably, the number of total attacks according to IDF data starts at a relatively low level, jumps starkly at the time of Operation Defensive Shield, and then flattens out. This suggests that the IDF measure is, in part, affected by the level of intelligence gathering within the Occupied Territories and may not strictly reflect the evolution of intended Palestinian violence over time. We are therefore cautious about over-interpreting these results. Nevertheless, the remarkable consistency in the results on successful targeted killings between the B'Tselem and IDF data point, at the very least, in the direction that increased targeted killings

${ }^{20}$ The peak of the quadratic function is attained at $\frac{1.34}{2 \times 0.23}=2.91$ successful targeted killings. 
may reduce subsequent levels of activity related to suicide attacks, although this effect occurs at levels of targeted killings that are almost never observed in the data. ${ }^{21}$

It is worth commenting on the differences between these results and those in Jaeger and Paserman (2008). They find that Israeli violence does not cause a significant Palestinian response in terms of realized violence. This result is essentially replicated in our results regarding non-targeted killing fatalities (which are about 85 percent of total Palestinian fatalities) in regressions at the daily, weekly, and monthly frequencies, although we do find a statistically significant effect for non-targeted killing Palestinian fatalities in some of our models. ${ }^{22}$ It is primarily the deaths of Palestinian leaders from targeted killings that appear to affect the Palestinian response. In the case of realized Palestinian violence (i.e. the regressions in which we use total Israeli fatalities as the dependent variable), we find a deterrent effect of successful targeted killings. In the case of intended violence (i.e. the regressions where we used intended suicide attacks), we find some evidence of an inverted-U shaped relationship with targeted killings, suggesting that at low levels of targeted killings the vengeance factor dominates and Palestinians are driven to intensify their efforts to respond violently; at higher levels, however, the incapacitation or deterrent effect dominates, and the overall level of Palestinian violence diminishes.

\footnotetext{
${ }^{21}$ Relative to months in which there were no successful targeted killings, the results suggest that suicide attacks would decline when there are at least 5.8 successful targeted killings. There are only three months in the data in which we observe 6 successful targeted killings.

${ }^{22}$ Because our data on targeted killings are limited to the time period covered by Zussman and Zussman (2006), our results here cover a different period than in Jaeger and Paserman (2007). When we limit ourselves to using only the data from B'Tselem and examine the entire period covered by Jaeger and Paserman (2007), the coefficients on other Palestinian fatalities in the Palestinian reaction function are no longer statistically significant.
} 


\section{Discussion and Conclusion}

Are targeted killings effective in reducing the level of Palestinian violence? The evidence presented here suggests that there may be a short-term incapacitation or deterrent effect of targeted killings in terms of realized Palestinian violence. We find little evidence to suggest, however, that this reduction occurs because of a decrease in the level of terrorist activity. When we examine how targeted killings affect intended violence, we find that at low levels, targeted killings actually increase the Palestinian efforts to respond with suicide attacks. Our results suggest that higher numbers of targeted killings perhaps lead to a reduction in subsequent intended Palestinian suicide attacks, but only at a level that has been rarely, if ever, observed during the Second Intifada.

Do suicide attacks affect subsequent Israeli violence? Our results consistently indicate that suicide attacks lead to increased levels of subsequent Palestinian fatalities. Israel clearly responds to both suicide attacks and other Israeli fatalities with lethal force in a regular and predictable way, with each successful suicide attack leading to approximately 7 additional Palestinian deaths, and each Israeli death caused by other means leading to about 1 additional Palestinian death. We find no evidence that Israel reacts to failed suicide attacks.

We do not find strong support for Bloom's $(2004,2005)$ assertion that suicide attacks and targeted killings follow a never-ending "tit-for-tat" pattern. Israel clearly reacts to suicide attacks, but targeted killings would appear to reduce subsequent Israeli fatalities. We do present suggestive evidence that targeted killings lead to elevated Palestinian activity related to suicide attacks (as measured by the IDF data on intended suicide attacks), but this activity does not seem to lead to increased levels of Israeli fatalities. 
Our results address the short-term effects of suicide attacks and targeted killings on subsequent violence. But are these policies effective in realizing the long-term goals of the Palestinians and Israelis? Here, of course, we do not have recourse to regression analysis and can only speculate about the longer-term effect of violence. One of the long-term goals of the Palestinians is withdrawal of Israeli settlements and troops from the Occupied Territories (Pape 2006). Israel's withdrawal from the Gaza Strip in the summer of 2005, while not necessarily solely a product of the suicide terror campaign during the Second Intifada, does suggest that Palestinian violence, and particular suicide attacks, can have an influence on Israeli policies, even at a cost of thousands of Palestinian and hundreds of Israeli lives. On the Israeli side, the level of Palestinian violence against Israelis has decreased substantially since the beginning of the Intifada. This is likely due, in part, to the increased use of targeted killings coupled with policies of increasing restrictions placed on movement between the Occupied Territories (e.g. the separation barrier) and vigilance. Given the relative long-term successes of the policies of suicide attacks and targeted killings (coupled with other deterrent policies), current and future conflicts with similar asymmetries in military power between the occupying and occupied populations may see continued use of these strategies. 


\section{REFERENCES}

Berrebi, Claude and Esteban F. Klor (2007) "Are Voters Sensitive to Terrorism? Direct Evidence from the Israeli Electorate," Unpublished Manuscript, The Hebrew University of Jerusalem.

Bloom, Mia M. 2004. "Palestinian Suicide Bombing: Public Support, Market Share and Outbidding." Political Science Quarterly, 119(1):61-88.

Bloom, Mia M. 2005. Dying to Kill: The Allure of Suicide Terror. New York: Columbia University Press.

Brophy-Baermann, Bryan and Conybeare, John A. C. 1994. "Retaliating against Terrorism: Rational Expectations and the Optimality of Rules versus Discretion," American Journal of Political Science, 38(1):196-210.

Bueno de Mesquita, Ethan and Dickson, Eric S. 2007 "The Propaganda of the Deed: Terrorism, Counterterrorism, and Mobilization." American Journal of Political Science, 51(2): 364381.

Byman, Daniel. 2006. “Do Targeted Killings Work?” Foreign Affairs 85(2):95-111.

David, Steven R. 2002. "Israel's Policy of Targeted Killing," Ethics and International Affairs 17(1): 111-126.

Enders, Walter and Sandler, Todd. 1993. "The Effectiveness of Antiterrorism Policies: A VectorAutoregression-Intervention Analysis.” American Political Science Review, 87(4):829-844.

Frisch, Hillel. 2006. "Motivation or Capabilities? Israeli Counterterrorism against Palestinian Suicide Bombings and Violence," Journal of Strategic Studies 29(5):843-869.

Granger, Clive W.J. 1969. "Investigating Causal Relations by Econometric Methods and CrossSpectral Methods," Econometrica, 37(3):424-438.

Gupta, Dipak K. and Kusum Mundra. 2005. "Suicide Bombings as a Strategic Weapon: An Empirical Investigation of Hamas and Islamic Jihad," Terrorism and Political Violence, 17(2): 573-598.

Jacobson, Daniel and Edward H. Kaplan. 2008. "Suicide Bombings and Targeted Killings in (Counter-) Terror Games," Journal of Conflict Resolution, forthcoming.

Jaeger, David A; Klor, Esteban F.; Miaari, Sami and Paserman, M. Daniele. 2008. "The Struggle for Palestinian Hearts and Minds: Violence and Public Opinion in the Second Intifada." Unpublished Manuscript, IZA. 
Jaeger, David A. and M. Daniele Paserman. 2006. "The Cycle of Violence? An Empirical Analysis of Fatalities in the Palestinian-Israeli Conflict," IZA Discussion Paper 1808, February.

Jaeger, David A. and M. Daniele Paserman. 2008. "The Cycle of Violence? An Empirical Analysis of Fatalities in the Palestinian-Israeli Conflict," American Economic Review, forthcoming.

Kaplan, Eben. 2006. "Backgrounder: Targeted Killlings", Council on Foreign Relations, http://www.cfr.org/publication/9627/ (last see 11 June 2007).

Kaplan, Edward H.; Mintz, Alex; and Mishal, Shal. 2006. "Tactical Prevention of Suicide Bombings in Israeli," Interfaces 36(6):553-561.

Kaplan, Edward H.; Mintz, Alex; Mishal, Shaul, and Samban Claudio. 2005. "What Happened to Suicide Bombings in Israel? Insights from a Terror Stock Model," Studies in Conflict and Terrorism, 28(2): 225-235.

Kydd, H. Andrew and Walter, Barbara F. 2002 "Sabotaging the Peace: The Politics of Extremist Violence," International Organizations 56(2): 263-296.

Pape, Robert A. 2003. "The Strategic Logic of Suicide Terrorism." American Political Science Review, 97(3):1-19.

Pape, Robert A. 2006. Dying to Win: The Strategic Logic of Suicide Terrorism. New York: Random House Trade Paperbacks.

Stein, Yael. 2003. "By Any Name Illegal and Immoral," Ethics and Internatioanl Affairs, 17(1):127-137.

White, Halbert. 1980. "A Heteroskedasticity-Consistent Covariance Matrix Estimator and a Direct Test for Heteroskedasticity," Econometrica, 48(4):817-838.

Zussman, Asaf, and Zussman, Noam. 2006. "Assassinations: Evaluating the Effectiveness of a Counterterrorism Policy," Journal of Economic Perspectives, 20(2):193-206. 
Figure 1

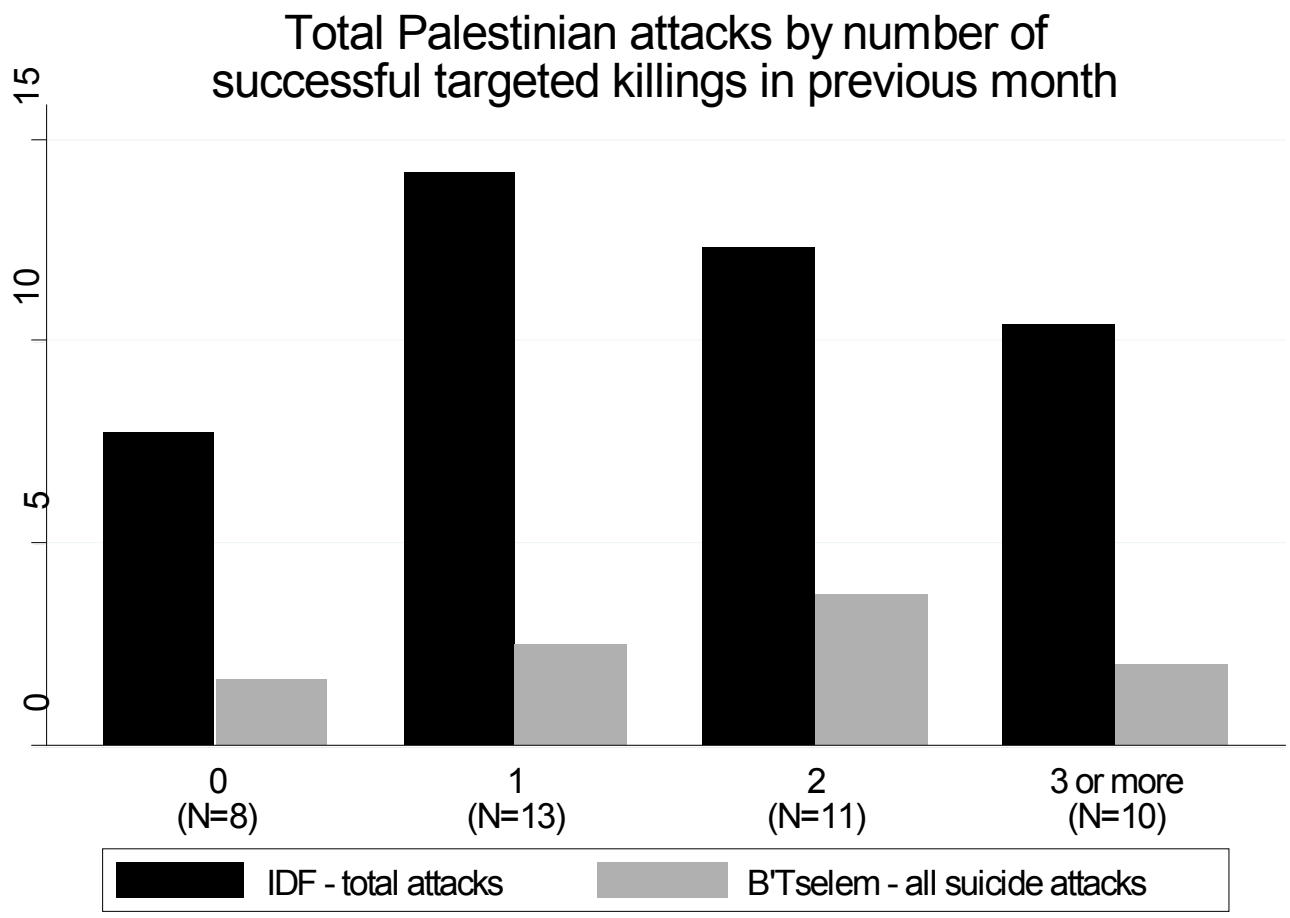

Source: Authors calculations based on data from B'Tselem and Zussman and Zussman (2006) 
Table 1

Israeli Fatalities in the Second Intifada, 29 September 2000 to 15 January 2005

\begin{tabular}{|c|c|c|c|c|c|c|}
\hline \multirow[b]{2}{*}{ Variable } & \multicolumn{5}{|c|}{ Year } & \multirow[b]{2}{*}{ Total } \\
\hline & 2000 & 2001 & 2002 & 2003 & 2004-05 & \\
\hline Total Israeli fatalities & 41 & 195 & 439 & 199 & 109 & 983 \\
\hline Israeli fatalities by suicide attacks & 0 & 79 & 215 & 137 & 54 & 485 \\
\hline Share of Israeli fatalities by suicide attacks & 0.000 & 0.405 & 0.490 & 0.688 & 0.495 & 0.493 \\
\hline Number of successful suicide attacks & 0 & 11 & 32 & 16 & 8 & 67 \\
\hline Number of unsuccessful suicide attacks & 2 & 14 & 26 & 6 & 7 & 55 \\
\hline Share of attacks that were successful & 0.000 & 0.440 & 0.552 & 0.727 & 0.533 & 0.549 \\
\hline 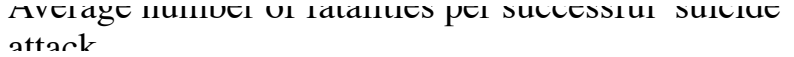 & - & 7.2 & 6.7 & 8.6 & 6.8 & 7.2 \\
\hline Average number of fatalities per all suicide attacks & 0.0 & 3.2 & 3.7 & 6.2 & 3.6 & 4.0 \\
\hline
\end{tabular}

Source: Authors' calculations from B'Tselem data. 
Table 2

Palestinian Fatalities in the Second Intifada, 29 September 2000 to 15 April 2004

\begin{tabular}{|c|c|c|c|c|c|c|}
\hline \multirow[b]{2}{*}{ Variable } & \multicolumn{5}{|c|}{ Year } & \multirow[b]{2}{*}{ Total } \\
\hline & 2000 & 2001 & 2002 & 2003 & 2004 & \\
\hline Total Palestinian fatalities (B'Tselem) & 286 & 470 & 1,038 & 587 & 216 & 2,597 \\
\hline \multicolumn{7}{|l|}{ B'Tselem Definition } \\
\hline Palestinians "targets" killed in targeted killings & 9 & 39 & 38 & 45 & 18 & 149 \\
\hline Other Palestinians killed in targeted killings & 6 & 7 & 26 & 43 & 10 & 92 \\
\hline Total Palestinians killed in targeted killings & 15 & 46 & 64 & 88 & 28 & 241 \\
\hline Share of total Palestinian fatalities in targeted killings & 0.052 & 0.098 & 0.062 & 0.150 & 0.130 & 0.093 \\
\hline Number of successful targeted killings & 9 & 24 & 19 & 24 & 6 & 82 \\
\hline Number unsuccesful targeted killings & 0 & 9 & 2 & 7 & 1 & 19 \\
\hline Share of targeted killings that were successful & 1.000 & 0.727 & 0.905 & 0.774 & 0.857 & 0.812 \\
\hline Average number of fatalities per targeted killing & 1.7 & 1.4 & 3.0 & 2.8 & 4.0 & 2.4 \\
\hline \multicolumn{7}{|l|}{ Zussman and Zussman Definition } \\
\hline Palestinians "targets" killed in targeted killings & 9 & 29 & 45 & 32 & 16 & 131 \\
\hline Other Palestinians killed in targeted killings & 6 & 26 & 74 & 64 & 16 & 186 \\
\hline Total Palestinians killed in targeted killings & 15 & 55 & 119 & 96 & 32 & 317 \\
\hline Share of total Palestinian fatalities in targeted killings & 0.052 & 0.117 & 0.115 & 0.164 & 0.148 & 0.122 \\
\hline Number of successful targeted killings & 10 & 30 & 50 & 36 & 8 & 134 \\
\hline Number of unsuccesful targeted killings & 0 & 10 & 5 & 8 & 1 & 24 \\
\hline Share of targeted killings that were successful & 1.000 & 0.750 & 0.909 & 0.818 & 0.889 & 0.848 \\
\hline Average number of fatalities per targeted killing & 1.5 & 1.4 & 2.2 & 2.2 & 3.6 & 2.0 \\
\hline
\end{tabular}

Note: Successful targeted killings are those in which the targeted individual was killed. Unsuccessful targeted killings are those in which the targeted individual was not killed. 
Table 3

Israeli Reaction Function:

Reaction to Successful and Unsuccessful Suicide Attacks

(weekly frequency)

\begin{tabular}{|c|c|c|c|c|}
\hline \multirow[b]{2}{*}{ Covariate } & \multicolumn{2}{|c|}{$\begin{array}{c}\text { Total Palestinian } \\
\text { Fatalities }\end{array}$} & \multicolumn{2}{|c|}{$\begin{array}{c}\text { Palestinian Fatalities in } \\
\text { Targeted Killings }\end{array}$} \\
\hline & Coefficient & Std. Err. & Coefficient & Std. Err. \\
\hline $\begin{array}{l}\text { Number of successful suicide attacks: } \\
\text { one week prior } \\
\text { two weeks prior }\end{array}$ & $\begin{array}{l}6.57 * * \\
0.87\end{array}$ & $\begin{array}{l}3.23 \\
1.81\end{array}$ & $\begin{array}{l}0.95 * * \\
0.31\end{array}$ & $\begin{array}{l}0.43 \\
0.41\end{array}$ \\
\hline $\begin{array}{l}\text { Number of failed suicide attacks: } \\
\text { one week prior } \\
\text { two weeks prior }\end{array}$ & $\begin{array}{r}-0.43 \\
5.64\end{array}$ & $\begin{array}{l}1.78 \\
3.81\end{array}$ & $\begin{array}{l}-0.26 \\
-0.36\end{array}$ & $\begin{array}{l}0.31 \\
0.26\end{array}$ \\
\hline $\begin{array}{l}\text { Number of other Israeli fatalities: } \\
\text { one week prior } \\
\text { two weeks prior }\end{array}$ & $\begin{array}{l}1.42 * * * \\
-0.26\end{array}$ & $\begin{array}{l}0.51 \\
0.45\end{array}$ & $\begin{array}{r}0.08 \\
-0.04\end{array}$ & $\begin{array}{l}0.08 \\
0.05\end{array}$ \\
\hline $\begin{array}{l}\text { Number of Palestian fatalities: } \\
\text { one week prior } \\
\text { two weeks prior }\end{array}$ & $\begin{array}{r}0.08 \\
-0.03\end{array}$ & $\begin{array}{l}0.10 \\
0.10\end{array}$ & $\begin{array}{l}-0.02 * * \\
-0.01\end{array}$ & $\begin{array}{l}0.01 \\
0.01\end{array}$ \\
\hline $\begin{array}{l}\text { Periods } \\
\text { Barak-Sharon } \\
\text { Sharon-9/11 } \\
\text { 9/12-ODS } \\
\text { ODS-Roadmap } \\
\text { Roadmap-Ceasefire } \\
\text { Ceasefire } \\
\text { Post-Ceasefire }\end{array}$ & $\begin{array}{l}\text { ref. } \\
-9.26 * * \\
-2.26 \\
-4.12 \\
-5.30 \\
-25.52 * * * \\
-25.25 *\end{array}$ & $\begin{array}{r}3.68 \\
4.38 \\
5.80 \\
3.73 \\
8.67 \\
13.55\end{array}$ & $\begin{array}{l}\text { ref. } \\
-0.28 \\
0.16 \\
0.04 \\
0.33 \\
-4.15 \\
-5.15\end{array}$ & $\begin{array}{l}0.54 \\
0.57 \\
0.91 \\
0.67 \\
2.71 \\
4.82\end{array}$ \\
\hline Length of Separation Barrier (10 km) & $0.15 *$ & 0.08 & 0.03 & 0.03 \\
\hline Constant & $10.81 * * *$ & 3.40 & $1.30 * * *$ & 0.48 \\
\hline$\chi^{2}$ for sig. of successful attempts ( $p$-value) & 4.41 & $(.110)$ & 4.89 & $(.087)$ \\
\hline$\chi^{2}$ for sig. of failed attempts ( $p$-value) & 2.19 & $(.335)$ & 2.08 & $(.353)$ \\
\hline$\chi^{2}$ for sig. of other fatalities ( $p$-value) & 8.09 & $(.017)$ & 2.22 & $(.330)$ \\
\hline$R^{2}$ & .340 & & .084 & \\
\hline
\end{tabular}

Note: Dependent variable is weekly number of Palestinian fatalities. Estimated with ordinary least squares with heteroskedasticity-consistent standard errors. * indicates estimated coefficient is statistically different from zero at the .10 level, $* *$ indicates estimated coefficient is statistically different from zero at the .05 level. *** indicates estimated coefficient is statistically different from zero at the .01 leve. Sample size is 216 weeks. Source: Authors' tabulations of data from B'Tselem from 29 September 2000 to 15 January 2005. 
Table 4

Israeli Reaction Function: Reaction to Successful and Unsuccesful Suicide Attacks

Robustness Checks

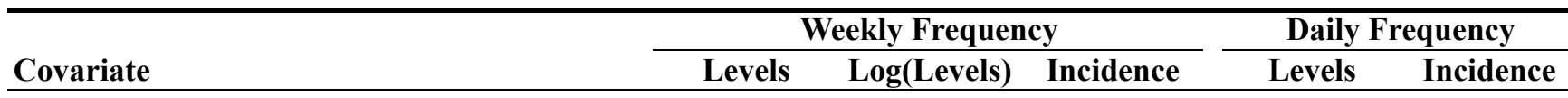

Number of successful suicide attacks:

one week prior

$+* *$

$+* *$

$+* *$

two weeks prior

Number failed suicide attacks:

one week prior

two weeks prior

Number of other Israeli fatalities:

one week prior

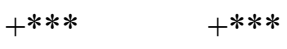

$+* * *$

$+* * *$

two weeks prior

Note: All models estimated with ordinary least squares. Heteroskedasticity-consistent standard errors. * indicates estimated coefficient is statistically different from zero at the .10 level, ** indicates estimated coefficient is statistically different from zero at the .05 level. $* * *$ indicates estimated coefficient is statistically different from zero at the .01 level. different from zero at the .01 level. Sample size is 216 weeks.

Source: Authors' tabulations of data from B'Tselem from 29 September 2000 to 15 January 2005. 
Table 5

Palestinian Reaction Functions:

Reaction to Successful and Unsuccessful Targeted Killing Attempts (weekly frequency)

\begin{tabular}{|c|c|c|c|c|}
\hline \multirow[b]{2}{*}{ Covariate } & \multicolumn{2}{|c|}{ Total Israeli Fatalities } & \multicolumn{2}{|c|}{$\begin{array}{l}\text { Israeli Fatalities in } \\
\text { Suicide Attacks }\end{array}$} \\
\hline & Coefficient & Std. Err. & Coefficient & Std. Err. \\
\hline $\begin{array}{l}\text { Number of successful targeted killings: } \\
\text { one week prior } \\
\text { two weeks prior }\end{array}$ & $\begin{array}{l}-1.12 * * \\
0.60\end{array}$ & $\begin{array}{l}0.45 \\
0.59\end{array}$ & $\begin{array}{l}-0.70 * * \\
0.78\end{array}$ & $\begin{array}{l}0.33 \\
0.56\end{array}$ \\
\hline $\begin{array}{l}\text { Number of failed targeted killings: } \\
\text { one week prior } \\
\text { two weeks prior }\end{array}$ & $\begin{array}{l}-0.35 \\
-1.22\end{array}$ & $\begin{array}{l}1.08 \\
0.91\end{array}$ & $\begin{array}{l}-0.14 \\
-0.72\end{array}$ & $\begin{array}{l}0.88 \\
0.75\end{array}$ \\
\hline $\begin{array}{l}\text { Number of other Palestinian fatalities: } \\
\text { one week prior } \\
\text { two weeks prior }\end{array}$ & $\begin{array}{l}0.09 * * \\
0.01\end{array}$ & $\begin{array}{l}0.05 \\
0.07\end{array}$ & $\begin{array}{l}0.04 \\
0.03\end{array}$ & $\begin{array}{l}0.03 \\
0.06\end{array}$ \\
\hline $\begin{array}{l}\text { Number of Israeli fatalities } \\
\text { one week prior } \\
\text { two weeks prior }\end{array}$ & $\begin{array}{l}0.04 \\
0.02\end{array}$ & $\begin{array}{l}0.09 \\
0.08\end{array}$ & $\begin{array}{l}-0.02 \\
-0.05\end{array}$ & $\begin{array}{l}0.07 \\
0.06\end{array}$ \\
\hline $\begin{array}{l}\text { Periods } \\
\text { Barak-Sharon } \\
\text { Sharon-9/11 } \\
\text { 9/12-ODS } \\
\text { ODS-Roadmap } \\
\text { Roadmap-Ceasefire } \\
\text { Ceasefire } \\
\text { Post-Ceasefire }\end{array}$ & $\begin{array}{l}\quad \text { ref. } \\
2.63 * \\
4.81 * * \\
6.98 * \\
2.38 * \\
2.78 \\
1.34\end{array}$ & $\begin{array}{l}1.40 \\
1.90 \\
3.19 \\
1.23 \\
4.97 \\
8.80\end{array}$ & $\begin{array}{r}\text { ref. } \\
2.57 * * \\
3.50 * * * \\
7.30 * * * \\
2.69 * * * \\
3.91 \\
1.99\end{array}$ & $\begin{array}{l}1.13 \\
1.35 \\
2.70 \\
1.03 \\
4.22 \\
7.66\end{array}$ \\
\hline Length of Separation Barrier (10 km) & -0.003 & 0.05 & 0.004 & 0.05 \\
\hline Constant & 1.06 & 1.14 & -0.91 & 0.83 \\
\hline $\begin{array}{l}\chi^{2} \text { for sig. of successful attempts ( } p \text {-value) } \\
\chi^{2} \text { for sig. of failed attempts ( } p \text {-value) } \\
\chi^{2} \text { for sig. of other fatalities ( } p \text {-value) }\end{array}$ & $\begin{array}{l}8.02 \\
1.88 \\
5.16\end{array}$ & $\begin{array}{l}(.018) \\
(.391) \\
(.076)\end{array}$ & $\begin{array}{l}6.91 \\
1.01 \\
3.70\end{array}$ & $\begin{array}{l}(.032) \\
(.604) \\
(.157)\end{array}$ \\
\hline$R^{2}$ & .181 & & .124 & \\
\hline
\end{tabular}

Note: Dependent variable is weekly number of Israeli fatalities. Estimated with ordinary least squares. Successful targeted killings are those in which the targeted individual was killed. Unsuccessful targeted killings are those in which the targeted individual was not killed. * indicates estimated coefficient is statistically different from zero at the .10 level, ** indicates estimated coefficient is statistically different from zero at the .05 level. Sample size is 189 weeks.

Source: Authors' tabulations of data from B'Tselem and Zussman and Zussman (2006) from 29 September 2000 to 30 April 2004. 


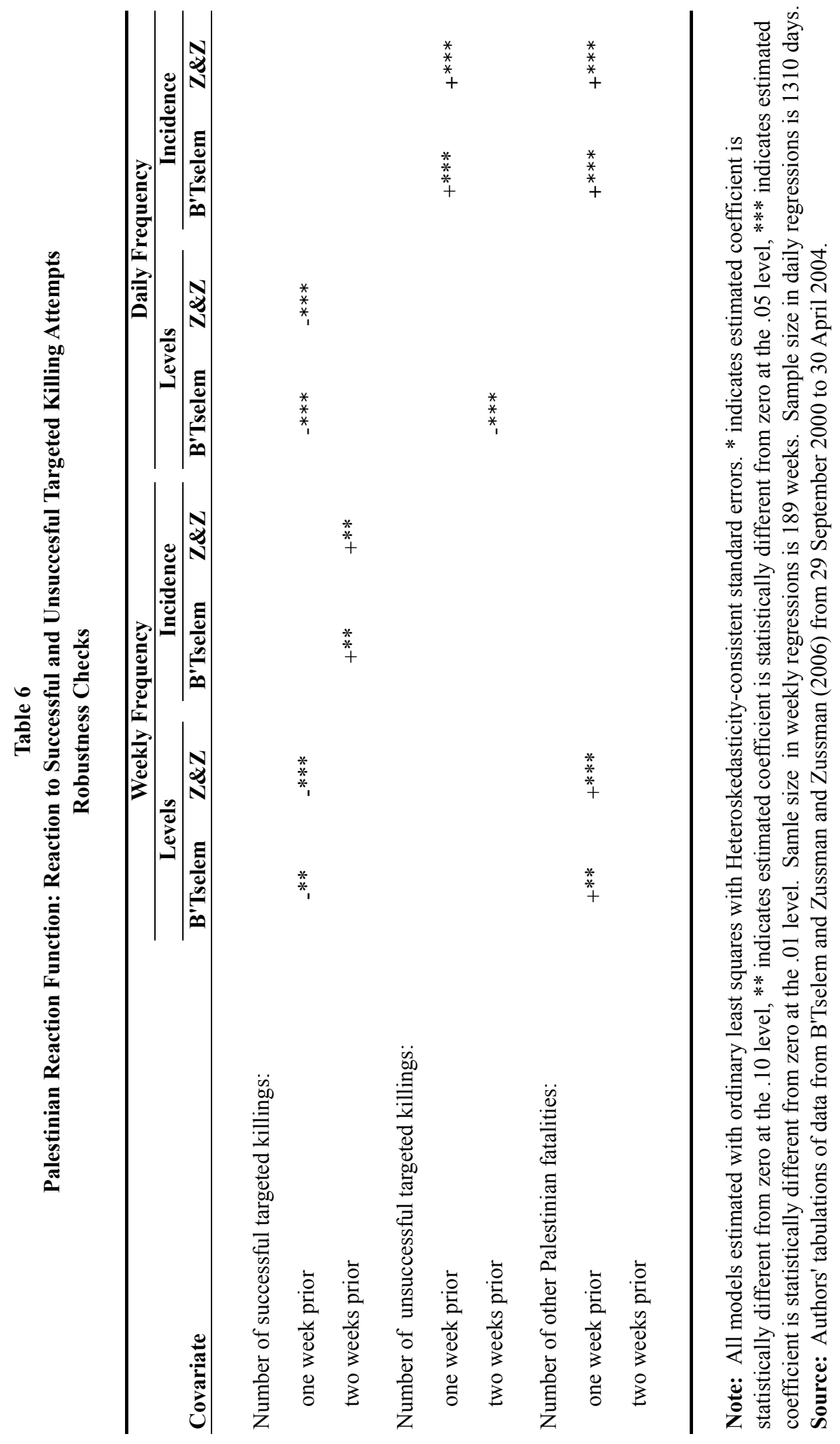


Table 7

Palestinian Reaction Function, Intended Suicide Attacks:

Reaction to Successful and Unsuccessful Targeted Killings

(weekly frequency)

\section{Covariate}

Number of successful targeted killings:

one week prior

two weeks prior

Number of failed targeted killings:

one week prior

two weeks prior

Number of other Palestinian fatalities:

one week prior

two weeks prior

Number of Israeli fatalities

one week prior

two weeks prior

Periods

Barak-Sharon

Sharon-9/11

9/12-ODS

ODS-Roadmap

Roadmap-Ceasefire

Ceasefire

Post-Ceasefire

Length of Separation Barrier (10 km)

Constant

$\chi^{2}$ for sig. of successful attempts ( $p$-value)

$\chi^{2}$ for sig. of failed attempts ( $p$-value)

$\chi^{2}$ for sig. of other fatalities ( $p$-value)

$R^{2}$
Coefficient Std. Err.

$\begin{array}{rr}-0.09 & 0.08 \\ 0.08 & 0.10 \\ & \\ -0.06 & 0.16 \\ -0.12 & 0.17\end{array}$

$\begin{array}{ll}0.004 & 0.01\end{array}$

$0.01 \quad 0.01$

$0.00 \quad 0.01$

$0.01 \quad 0.01$

\begin{tabular}{ll}
\multicolumn{2}{c}{ ref. } \\
$0.41 * *$ & 0.21 \\
$0.98 * * *$ & 0.28 \\
1.13 & 0.58 \\
$0.33 * *$ & 0.16 \\
-0.22 & 0.63 \\
-0.98 & 1.00 \\
0.01 & 0.01 \\
-0.01 & 0.19
\end{tabular}

1.95

$(.378)$

$0.63 \quad(.730)$

$0.80 \quad(.671)$

.190

Note: Dependent variable is number of days with total successful and failed suicide attacks. Estimated with ordinary least squares with

heteroskedasticity-consistent standard errors. Successful targeted killings are those in which the targeted individual was killed. Unsuccessful targeted killings are those in which the targeted individual was not killed. * indicates estimated coefficient is statistically different from zero at the .10 level, ** indicates estimated coefficient is statistically different from zero at the .05 level. Number of observations is 189 weeks.

Source: Authors' tabulations of data from B'Tselem and Zussman and Zussman (2006) from 29 September 2000 to 30 April 2004. 
Table 8

Palestinian Reaction Function, Intended Violence:

Reaction to Successful and Unsuccessful Assassination Attempts

(monthly frequency)

\begin{tabular}{|c|c|c|c|c|}
\hline \multirow[b]{2}{*}{ Covariate } & \multicolumn{2}{|c|}{$\begin{array}{c}\text { Dependent variable: } \\
\text { total sucessful and failed } \\
\text { suicide attacks (B'Tselem) }\end{array}$} & \multicolumn{2}{|c|}{$\begin{array}{c}\text { Dependent variable: } \\
\text { total successful and failed } \\
\text { suicide attacks (IDF) } \\
\end{array}$} \\
\hline & Coefficient & Std. Err. & Coefficient & Std. Err. \\
\hline $\begin{array}{l}\text { Number of successful targeted killings: } \\
\text { one month prior (linear) } \\
\text { one mont prior (quadratic) }\end{array}$ & $\begin{array}{l}1.34 * \\
-0.23\end{array}$ & $\begin{array}{l}0.68 \\
0.14\end{array}$ & $\begin{array}{c}2.80 * * \\
-0.43 *\end{array}$ & $\begin{array}{l}1.20 \\
0.22\end{array}$ \\
\hline $\begin{array}{l}\text { Number of failed targeted killings: } \\
\text { one month prior (linear) } \\
\text { one month prior (quadratic) }\end{array}$ & $\begin{array}{r}0.62 \\
-0.34\end{array}$ & $\begin{array}{l}1.28 \\
0.49\end{array}$ & $\begin{array}{r}-1.40 \\
0.78\end{array}$ & $\begin{array}{l}3.06 \\
1.09\end{array}$ \\
\hline $\begin{array}{l}\text { Number of other Palestinian fatalities: } \\
\text { one month prior (linear) } \\
\text { one month prior (quadratic) }\end{array}$ & $\begin{array}{r}-0.02 \\
0.0001\end{array}$ & $\begin{array}{c}0.03 \\
0.0001\end{array}$ & $\begin{array}{r}0.01 \\
-0.00003\end{array}$ & $\begin{array}{c}0.06 \\
0.0002\end{array}$ \\
\hline Number of Israeli fatalitites one month prior & $-0.04 *$ & 0.02 & $-0.09 * *$ & 0.04 \\
\hline $\begin{array}{l}\text { Periods } \\
\text { Barak-Sharon } \\
\text { Sharon-9/11 } \\
\text { 9/12-ODS } \\
\text { ODS-Roadmap } \\
\text { Roadmap-Ceasefire } \\
\text { Ceasefire } \\
\text { Post-Ceasefire }\end{array}$ & $\begin{array}{l}0.93 \\
5.13 * * \\
4.46 * * * \\
1.43 \\
1.80 \\
-0.37\end{array}$ & $\begin{array}{l}1.27 \\
2.18 \\
0.89 \\
1.19 \\
3.75 \\
4.68\end{array}$ & $\begin{array}{l}\text { ref. } \\
0.50 \\
7.08 * * \\
13.83 * * * \\
15.79 * * * \\
18.41 * \\
15.14\end{array}$ & $\begin{array}{r}2.36 \\
3.27 \\
1.78 \\
2.06 \\
9.00 \\
13.25\end{array}$ \\
\hline Length of Separation Barrier (10 km) & 0.01 & 0.02 & -0.02 & 0.08 \\
\hline Constant & 1.14 & 1.63 & 0.81 & 2.90 \\
\hline$R^{2}$ & \multicolumn{2}{|c|}{.506} & \multicolumn{2}{|c|}{.735} \\
\hline
\end{tabular}

Note: All models estimated with ordinary least squares with heteroskedasticity-consistent standard errors.

Successful targeted killings are those in which the targeted individual was killed. Unsuccessful targeted killings are those in which the targeted individual was not killed. * indicates estimated coefficient is statistically different from zero at the .10 level, ** indicates estimated coefficient is statistically different from zero at the .05 level. *** indicates estimated coefficient is statistically different from zero at the .01 level. Number of observations is 42 months. 